\title{
PENGARUH KONSENTRASI GULA YANG BERBEDA DENGAN PENAMBAHAN KAYU MANIS (Cinnamomum burmannii) PADA MANISAN RUMPUT LAUT (Eucheuma cottonii) TERHADAP TINGKAT PENERIMAAN KONSUMEN
}

\author{
Marinana maliti, Sonya Titin Nge, Aprilliana Ballo \\ Program studi pendidikan Biologi, Fakultas Keguruan dan IImu Pendidikan Universitas Kristen Artha wacana-Kupang \\ Corresponden author: Sonyatitin_nge@gmail.com,
}

\begin{abstract}
Abstrak
Rumput laut merupakan tumbuhan laut yang mempunyai nilai ekonomis dan banyak pemanfaatannya. Pemanfaatan rumput laut sebagai sumber kesehatan dan gizi karna memiliki kandungan karbohidrat (gula atau vegetable gum), protein, sedikit lemak dan abu yang sebagian besar merupakan senyawa garam natrium dan kalium. Analisis proksimat dilakukan untuk mengetahui komponen utama dari suatu bahan makanan penelitian ini telah dilaksanakan pada bulan 18 September - 05 Oktober 2018 di lab biologi UKAW dan balai pengawas obat dan makan (BPOM) Kupang Nusa Tenggara Timur. Berdasarkan penelitian yang dilakuan maka hasil analisis organoleptik dari warna, aroma, tekstur dan rasa manisan rumput laut (Eucheuma cottonii) yang paling disukai panelis adalah pada perlakuan $\mathrm{K}_{3}$, kadar air pada perlakuan $\mathrm{K}_{3}$ yaitu 17,48\%-18,34\% dan kadar gula total yaitu pada perlakuan $\mathrm{K}_{3}=25,09 \%$. Hal ini disebabkan karna pemberian gula yang berbeda pada manisan rumput laut dengan penambahan kayu manis yang dapat mempengaruhi tingkat kesukaan, kadar air serta kadar gula total dari tingkat penerimaan konsumen pada manisan rumput laut tersebut.
\end{abstract}

Kata kunci : Eucheuma cottonii dan Cinnamomum burmannii, gula pasir

\begin{abstract}
Seaweed is a sea plant that has economic value and has many uses. Utilization of seaweed as a source of health and nutrition because it contains carbohydrates (sugar or vegetable gum), protein, less fat and ash which are mostly sodium and potassium salt compounds. Proximate analysis was carried out to find out the main components of a food ingredient. This research was carried out on September 18 - October 5, 2018 in the UKAW biology lab and the drug and eating control agency (BPOM) Kupang, East Nusa Tenggara. Based on the research conducted, the results of organoleptic analysis of the color, aroma, texture and taste of candied seaweed (Eucheuma cottonii) most favored by panelists were in the $\mathrm{K} 3$ treatment, the water content in the $\mathrm{K} 3$ treatment was $17.48 \%-18.34 \%$ and the sugar content total ie in the $\mathrm{K} 3$ treatment $=25.09 \%$. This is because the provision of different sugars on candied seaweed with the addition of cinnamon that can affect the level of preference, water content and total sugar content of the level of consumer acceptance of the seaweed candied.
\end{abstract}




\section{PENDAHULUAN}

\section{Indigenous Biologi \\ Jurnal pendidikan dan Sains Biologi \\ Volume 2(1) $2019(8-20)$}

\section{Latar Belakang}

Indonesia sebagai Negara kepulauan dengan panjang garis pantai $81.000 \mathrm{~km}$ serta terdiri dari $70 \%$ dan $30 \%$ daratan merupakan kawasan pesisir laut yang memiliki berbagai sumber daya hayati yang sangat besar dan beragam. Sumber daya hayati merupakan potensi pembangunan yang sangat penting untuk pertumbuhan ekonomi baru (Firdarini, 2016). Budidaya rumput laut di Indonesia telah dikembangkan di beberapa daerah seperti Nusa Tenggara Barat (NTB), Nusa Tenggara Timur (NTT), Sulawesi, Sumatera, Jawa serta di daerah lainnya (Pongarrang dkk, 2013). Provinsi Nusa Tenggara Timur (NTT) merupakan provinsi kepulauan yang terletak di sebelah selatan wilayah Indonesia dengan luas wilayah laut $200.000 \mathrm{~km}^{2}$ (di luar ZEEI) di dalamnya terdapat sumberdaya kelautan dan perikanan yang dapat dikembangkan untuk kepentingan masyarakat. Kabupaten di NTT yang mengembangkan usaha budidaya rumput laut antara lain: Kabupaten Kupang, Sabu Raijua, Rote Ndao, Alor, Lembata, Flores Timur, Sikka, Sumba Timur dan Manggarai Barat (Risamasu, 2014).

Rumput laut merupakan tumbuhan laut yang mempunyai nilai ekonomis dan banyak pemanfaatannya. Pemanfaatan rumput laut sebagai sumber kesehatan dan gizi karena memiliki kandungan karbohidrat (gula atau vegetable gum), protein, sedikit lemak dan abu yang sebagian besar merupakan senyawa garam natrium dan kalium. Rumput laut banyak mengandung vitamin $A$ (B karoten), B1, B2, B6, B12, C, serta mineral seperti kalium, kalsium, fosfor, natrium, zat besi dan yodium (Surati dkk., 2016). Selain digunakan untuk pengobatan langsung, olahan rumput laut juga dapat dijadikan agar-agar, algalin, karaginan (carrageenan) dan fulsaleran (furcellarn) yang merupakan bahan baku penting dalam industri makanan seperti tepung, farmasi, kosmetik, pangan, dan lain-lain. Rumput laut banyak diolah dalam bentuk kering setelah proses penjemuran berupa makanan siap dikonsumsi seperti dodol, minuman, dan manisan (Dharma dkk., 2012)

Sebagaian besar rumput laut hanya digunakan dalam bentuk kering, oleh karena itu perlu adanya diversifikasi produk olahan dari rumput laut dalam bentuk lain salah satunya dalam bentuk manisan. Menurut Hamzah dan Sribudisni (2010) manisan merupakan salah satu bentuk pangan olahan yang dibuat dengan proses penambahan gula dengan kadar air tinggi sehingga manisan dapat disimpan dalam jangka waktu yang relatif lama. Penambahan gula dilakukan untuk memberikan rasa manis, memperbaiki tekstur dan mencegah tumbuhnya mikroorganisme pembusuk karena dapat menurunkan kadar air (Ga dkk., (2017). Manisan rumput laut yang hanya menggunakan larutan gula saja cita rasa dan aroma yang ditimbulkannya kurang enak karena pengaruh bau rumput laut tersebut masih ada. Cara yang digunakan untuk meningkatkan cita rasa rumput laut tersebut adalah dengan penambahan zat tambahan alami seperti kayu manis. Penggunaan larutan kayu manis akan memberikan warna, aroma, cita rasa yang khas sehingga dapat menghilangkan aroma dan cita rasa bau amis (Riyadi, 2007). Menurut Standar Nasional Indonesia, syarat mutu manisan kering adalah mempunyai kadar air maksimum $25 \%$, keadaan (kenampakan, bau, dan rasa) normal, tidak berjamur dan gula yang dihitung sebagai sukrosa minimum $45 \%$. Penelitian ini bertujuan untuk mengetahui kadar air manisan, uji gula manisan dan tingkat penerimaan konsumen terhadap manisan rumput laut (Eucheuma cottonii) yang diberi perlakuan konsentrasi gula yang berbeda dan tambahan kayu manis.

\section{METODE PENELITIAN}

\section{Tempat dan Waktu Penelitian}

Penelitian ini dilaksanakan pada 18 Septembar 2018 - 25 September 2018 di Laboraturium Biologi dan dilanjutkan di Balai Pemeriksaan Obat dan Makanan (BPOM) Kupang.

\section{Alat dan Bahan}

Alat

Pada proses pembuatan manisan rumput laut diperlukan alat-alat yang akan digunakan dalam peneltian ini antara lain : Timbangan analitik digunakan untuk menimbang rumput laut dan kayu manis, oven untuk mengeringkan rumput laut, gelas ukur untuk menyimpan manisan rumput laut untuk dikeringkan dalam oven, desikator menghilangkan air dan kristal dari hasil pemurnian, pisau 
untuk memotong rumput laut sehingga mempermudah peresapan larutan ke dalam bahan baku, papan bedah utuk memotong rumput laut, kompor dan panci digunakan untuk memasak air panas untuk mencuci rumput laut, baskom menyimpan bahan seperti rumput laut, boks untuk menyimpan rumput laut saat pengambilan sampel .

\section{Bahan}

Bahan-bahan yang digunakan dalam penelitian ini terdiri dari, rumput laut Eucheuma cottonii yang di ambil langsung dari pantai Bolok. Kayu manis bubuk untuk menghilangkan aroma pada rumput laut dan gula pasir untuk membah rasa manis pada pembuatan manisan, sedangkan air matang untuk mencuci rumput laut. Bahan kimia yang digunakan dalam penelitian ini terdiri dari, natrium tiosulfat $\left(\mathrm{NaS}_{2} \mathrm{O}_{3}\right)$ untuk memurnikan cairan, natrium hidroksida (NAOH) $30 \%$ untuk membersihkan selulosa kayu dari material yang tidak diinginkan, aquades yaitu sebagai pelarut pada saat melarutkan senyawa. $\mathrm{Pb}$ asetat sebagai larutan penjernih dan mengendapkan asamasam organik, asam klorida ( $\mathrm{HCL}$ ) untuk pengawetan, $\mathrm{KI} 30 \%, \mathrm{H}_{2} \mathrm{SO}_{4} 25 \%, \mathrm{NaS}_{2} \mathrm{O}_{3}, \mathrm{NaCl}$ untuk menetralkan dan mengawetkan, fenoftalein sebagai indikator dalam asam-basah.

\section{Prosedur Kerja}

\section{Pengambilan Sampel}

Pengambilan sampel Euchema cottonii diambil secara langsung di Pantai Bolok, Kecamatan Kupang Barat.

\section{Prosedur Pembuatan Manisan Rumput Laut}

Bahan baku rumput laut yang dipakai yaitu masih segar dan tidak berjamur. Rumput laut ditimbang kemudian dicuci dan dibersihkan dari kotoran berupa pasir yang melekat pada rumput laut kemudian dicuci kembali dengan air tawar sebanyak 3x lalu direndam. Perendaman dilakuan dengan air tawar sebanyak 3 hari berturut-turut agar rumput laut tidak berlendir. Setiap 12 jam sekali air tawar diganti. Setelah perendeman salama 3 hari, air ditiriskan. Penghalusan rumput laut dilkukan setelah penirisan. Untuk pembuatan kayu manis, kayu manis bubuk dan gula yang sudah disiapkan dibuat larutan dengan penambahan air tawar matang hingga mencapai $100 \mathrm{ml}$, lalu larutan dimasukan ke dalam wadah yang berisi rumput laut kemudian selama 1 hari. Kemudian dilakukan proses pengeringan oven selama 18 jam dengan suhu $50^{\circ} \mathrm{C}$.

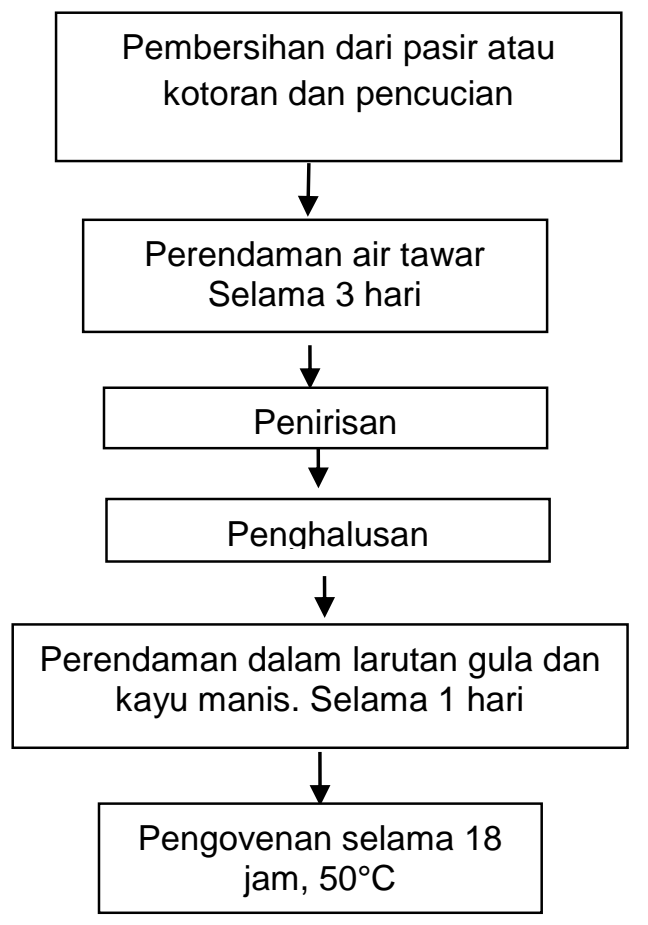

Gambar 1. Skema Pembuatan Manisan Rumput Laut Kering

Metode Penelitian 
Metode penelitian ini dilakukan dalam 2 tahap yaitu penelitian pendahuluan yang bertujuan untuk mengetahui konsentrasi kayu manis yang disukai panelis, kemudian dilakuan penelitian utama berupa proses perlakuan kering dan basah dari konsentrasi terpilih dari penelitian pendahuluan yang dilanjutkan dengan analisis kimia dan organoleptik.

\section{Penelitian Pendahuluan}

Pada penelitian pendahuluan dilakuan proses pembuatan manisan rumput laut dengan perlakuan penambahan rumput laut dengan konsentrasi gula yang berbeda. Ada 4 perlakuan yang dilakuan dalam penelitian ini yaitu penambahan kayu manis $0 \mathrm{gr}$, dan $10 \mathrm{gr}$, serta penambahan gula yaitu $0 \mathrm{gr}$ (sebagai kontrol), $50 \mathrm{gr}, 75 \mathrm{gr}$ dan $100 \mathrm{gr}$. Adapun formula manisan rumput laut per 100 gram pada penelitian pendahuluan.

Tabel 1. Rancangan perlakuan

\begin{tabular}{lcccc}
\hline Bahan & \multicolumn{4}{c}{ KETERANGAN } \\
\cline { 2 - 5 } & $\mathrm{K}_{0}$ & $\mathrm{~K}_{1}$ & $\mathrm{~K}_{2}$ & $\mathrm{~K}_{3}$ \\
\hline $\begin{array}{l}\text { Rumput } \\
\text { Laut }\end{array}$ & $100 \mathrm{gr}$ & $100 \mathrm{gr}$ & $100 \mathrm{gr}$ & $100 \mathrm{gr}$ \\
\hline Gula & $0 \mathrm{gr}$ & $50 \mathrm{gr}$ & $75 \mathrm{gr}$ & $100 \mathrm{gr}$ \\
\hline $\begin{array}{l}\text { Kayu } \\
\text { Manis }\end{array}$ & $0 \mathrm{gr}$ & $10 \mathrm{gr}$ & $10 \mathrm{gr}$ & $10 \mathrm{gr}$ \\
\hline
\end{tabular}

\section{Penelitian Utama}

Pada tahapan ini kegiatan yang dilakukan adalah pemberian perlakuan kering dari konsentrasi terpilih pada pada penelitian pendahuluan yang dilanjutkan dengan menganalisis kandungan manisan berupa uji kadar air, uji kadar gula serta uji organoleptik skala hedonik dengan jumlah penelis 20 orang.

\section{Uji Proksimat Rumput Laut \\ Analisis Kadar Air}

Prinsip analisis kadar air adalah proses penguapan air dari suatu bahan dengan cara pemanasan. Penentuan kadar air didasarkan pada perbedaan berat sampel sebelum dan sesudah dikeringkan. (Kusumaningrum dkk., 2013) Prosedur analisa kadar air adalah sebagai berikut:

1. Cawan kosong yang akan digunakan dikeringkan dalam oven selama 15 menit, kemudian didinginkan selama 30 menit dalam desikator, setelah dingin beratnya ditimbang.

2. Sampel ditimbang sebanyak $\pm 5 \mathrm{~g}$ lalu dimasukkan dalam cawan kemudian dikeringkan dalam oven selama 6 jam pada suhu $105^{\circ} \mathrm{C}$.

3. Cawan kemudian didinginkan dalam desikator selama 30 menit dan setelah dingin ditimbang kembali.

4. Kemudian setelah ditimbang, cawan tersebut dikeringkan dalam oven kembali sehingga didapat berat konstan.

5. Persentase kadar air dapat dihitung dengan rumus sebagai berikut:

Kadar air $(\%)=$

$$
\frac{a-b}{a} \times 100 \%
$$

Keterangan :

$$
\begin{aligned}
& a=\text { berat sampel awal }(\mathrm{gr}) \\
& \mathrm{b}=\text { berat sampel akhir }(\mathrm{gr})
\end{aligned}
$$

\section{Uji Kadar Gula Total- Metode Luff Schoorl (SNI-01-2892-1992)}

a. Timbang sebanyak 2 gram sampel dan masukan ke dalam labu ukur $250 \mathrm{ml}$ tambahkan air dan kocok

b. Tambahkan $5 \mathrm{ml} \mathrm{Pb}$ Asetat setengah basa dan goyangkan

c. tambahkan 1 tetes larutan (NH4)2HPO4 10\% (bila tiak timbul endapan putih maka penambahan $\mathrm{Pb}$ asetat setengah basa suah cukup) 
d. Tambahkan $15 \mathrm{ml}$ larutan (NH4)2HPO4 10\% untuk menguji apakah $\mathrm{Pb}$ asetat setengah basah suah diendapkan seluruhnya, teteskan 1-2 tetes (NH4)2HPO4 10\%. Apabila tidak timbul endapan berarti penambahan (NH4)2HPO4 10\% suah cukup

e. Goyangkan dan tepatkan isi-isi labu ukur sampai tanda garis dengan air suling, kocok 12 kali biarkan dan saring

f. Pipet $10 \mathrm{ml}$ larutan hasil penyaringan dan masukkan ke dalam erlenmeyer $500 \mathrm{ml}$

g. Tambahkan $15 \mathrm{ml}$ air suling dan 25 larutan luff (dengan pipet) serta beberapa butir batu didih

h. Panaskan terus menerus selama 10 menit (pakai stopwatch) kemuian angkat dan segera dinginkan dalam bak berisi es (jangan digoyang)

i. Setelah dingin tambahkan $10 \mathrm{ml}$ larutan $\mathrm{KI} 20 \%$ dan $25 \mathrm{ml} \mathrm{H}_{2} \mathrm{SO}_{4} 25 \%$ (hati-hati terbentuk gas $\mathrm{CO}_{2}$ )

j. Titran dengan larutan tio $0.1 \mathrm{~N}$ dengan larutan kanji 0,5 sebagai indikator, misalkan dibutuhkan $\mathrm{V} 2 \mathrm{ml}$ tio $0,1 \mathrm{~N}$

k. Kerjakan penetapan blanko dengan $25 \mathrm{ml}$ larutan luff, misalkan ibutuhkan $\mathrm{V} 2 \mathrm{ml}$ tio $0,1 \mathrm{~N}$ Perhitungan :

(V2-V1) ml tio yang dibutuhkan oleh contoh dijadikan 0,1000 N kemudian cari beberapa mg. Glukosa yang tertera untuk $\mathrm{ml}$ tio yang dipergunakan (misalnya W1 mg)

$\%$ gula sebelum inversi $=\mathrm{W} 1 \times \mathrm{FP}$

Keterangan :

$\mathrm{W} 1=$ glukosa, $\mathrm{mg}$

$\mathrm{FP} \quad=$ Faktor pengenceran

$\mathrm{W} \quad=$ Bobot contoh $(\mathrm{mg})$

\section{Uji Organoleptik}

Uji organoleptik merupakan uji yang dilakukan dengan memanfaatkan kepekaan indera manusia sebagai instrumennya. Pengujian dilakukan terhadap manisan rumput laut yang telah ditambahkan gula. Adapun parameter pada uji organoleptik meliputi rasa, aroma, warna, dan tekstur. Pengamatan dilakukan berdasarkan tingkat kesukaan panelis tidak terlatih sebanyak 20 orang dengan menggunakan skala uji kesukaan (Tampubolon, 2013)

Tabel 2. Uji kesukaan yang di gunakan dalam pengujian organoleptik manisan Rumput laut

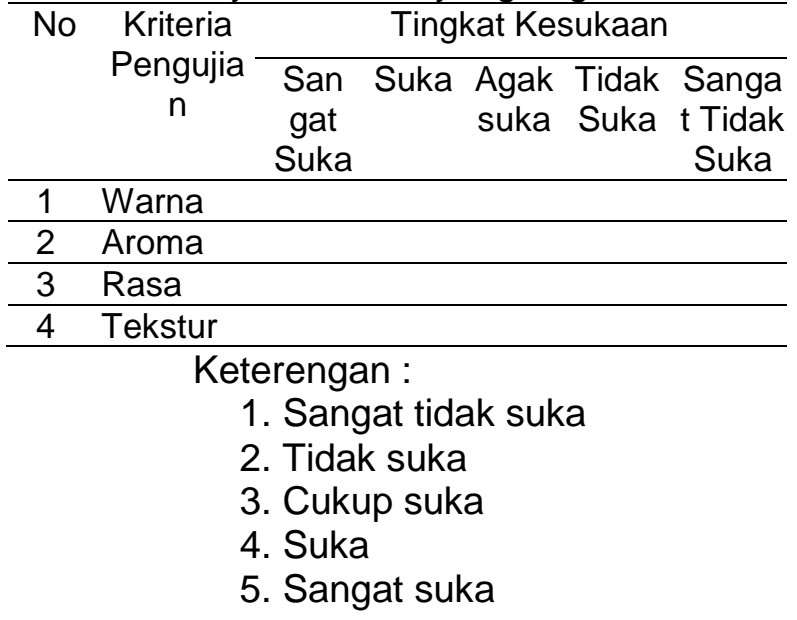

\section{Teknik Analisis Data}

Data hasil penelitian dianalisa menggunakan analisis sidik ragam (anova) untuk mengetahui pengaruh konsentrasi gula yang berbeda pada manisan rumput laut terhadap tingkat penerimaan konsumen.

\section{Manisan}


Manisan adalah salah satu produk makanan awetan yang dibuat dengan metode penggulaan atau salah satu jenis makanan ringan yang menggunakan gula pasir sebagai pemanis dan pengawet karena dapat mencegah pertumbuhan bakteri, ragi, dan kapang. Manisan bisa dibuat dengan bahan dasar apa saja salah satunya adalah rumput laut (Eucheuma cottonii). Manisan rumput laut dibuat dengan 4 perlakuan yaitu penambahan gula dengan konsentrasi $0 \mathrm{gr}, 50 \mathrm{gr}, 75 \mathrm{gr}$ dan $100 \mathrm{gr}$ dengan penambahan kayu manis (Cinnamomum burmannii) sebanyak $20 \mathrm{gr}$ pada 4 perlakuan. Hal ini bertujuan untuk mengetahui pembuatan manisan rumput laut dengan penambahan kayu manis, mengetahui pengaruh penambahan gula dan kayu manis terhadap cita rasa dan mutu manisan rumput laut, serta mengetahui tingkat kesukaan panelis terhadap manisan rumput laut (Eucheuma cottonii) yang dihasilkan dengan penambahan kayu manis. Rumput laut yang diambil secara langsung di Desa Bolok Kecamatan Kupang Barat Kabupaten Kupang, rumput laut yang dipilih merupakan lumput laut masih segar.

\section{Uji Organoleptik}

\section{a. Warna}

Warna merupakan sifat produk yang telah dipandang sebagai sifat fisik (obyektif) dan sifat organoleptik (subyektif). Warna sebagai sifat organoleptik adalah sebagai manifestasi dari sinar yang dapat merangsang alat indera mata dan dapat menghasilkan kesan psikologik diantara sifat warna. Warna suatu benda dapat ditentukan oleh 4 hal yaitu adanya sinar sebagai sumber penerang yang menyinari benda, sifat absorpsi dan refleksi spectra dari benda yang disinari, kondisi lingkungan benda dan kondisi subyek yang melihat benda. (Kusnandar dan Andarwulan, 2004)

Pada gambar 2 memperlihatkan bahwa nilai persentase warna berkisar antara 23\%-29\%. Untuk lebih jelasnya melihat tingkat kesukaaan panelis terhadap nilai warna manisan rumput laut (Eucheuma cottonii) dengan jenis konsentrasi yang berbeda dapat dilihat pada gambar 3 .

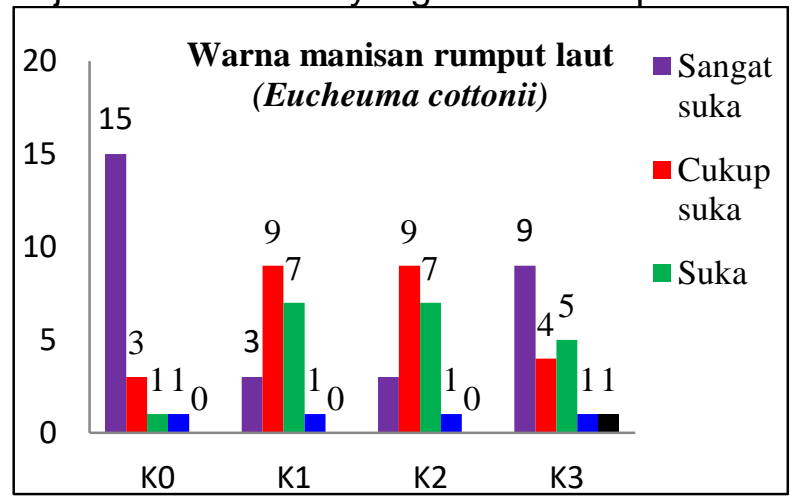

Gambar 2. Histogram tingkat kesukaan panelis terhadap warna manisan rumput Laut dengan jenis konsentrasi gula yang berbeda dengan penambahan kayu manis.

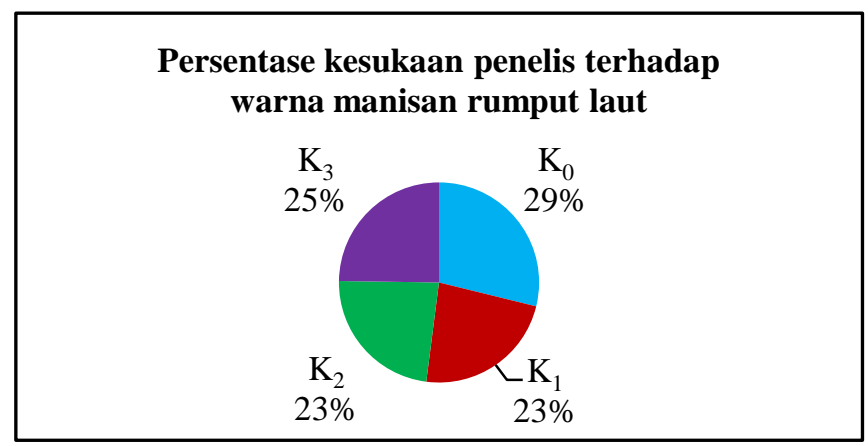

Gambar 3. Persentase penelis terhadap warna manisan rumput laut dengan jenis gula yang berbeda dengan penambahan kayu manis.

Pada gambar 3 memperlihatkan bahwa panelis lebih menyukai warna pada perlakuan $\mathrm{K}_{0}$ dengan persentase $29 \%$, dibandingkan dengan perlakuan $\mathrm{K}_{1}$ dan $\mathrm{K}_{2}$ yaitu $23 \%$ dan $\mathrm{K}_{3} 25 \%$ karena 
pada pelakuan $\mathrm{K}_{0}$ manisan rumput laut berwarna hijau, dari pada perlakuan $\mathrm{K}_{1}$ dan $\mathrm{K} 2$ yang berwarna kuning kecoklatan, dan perlakuan $\mathrm{K}_{3}$ berwarna coklat muda. Perubahan warna ini terjadi pada saat proses pencampuran gula dan kayu manis $10 \mathrm{gr}$ pada perlakuan $\left(\mathrm{K}_{1}, \mathrm{~K}_{2}\right.$ dan $\left.\mathrm{K}_{3}\right)$ dan pada $\mathrm{K}_{0}$ (sebagai kontrol) yang tidak dicampurkan gula dan kayu manis sehingga penelis lebih menyukai perlakuan $\mathrm{K}_{0}$. Hal ini menunjukan bahwa kayu manis memberikan pengaruh warna yang signifikan karena kayu manis mempunyai zat warna coklat (Khan dkk, 2003) yang bila dicampurkan dalam bahan makanan akan mempengaruhi warna makanan tersebut (Riyadi D, 2007).

\section{b. Aroma}

Aroma manisan rumput laut diuji dengan indera penciuman. Aroma umumnya diperoleh dengan menganalisa hasil penciuman pada produk pangan. Aroma mempunyai peranan yang sangat penting dalam penentuan derajat penilaian dan kualitas bahan pangan. Selain bentuk dan warna, bau atau aroma akan berpengaruh dan menjadi perhatian utama pada konsumen (Gaffar dkk., 2017).

Pada pembuatan manisan rumput laut ditambahan kayu manis dimaksudkan untuk menetralkan aroma khas rumput laut. Tingkat penerimaan panelis terhadap aroma manisan rumput laut (Eucheuma cotonii) dapat gambar 4.

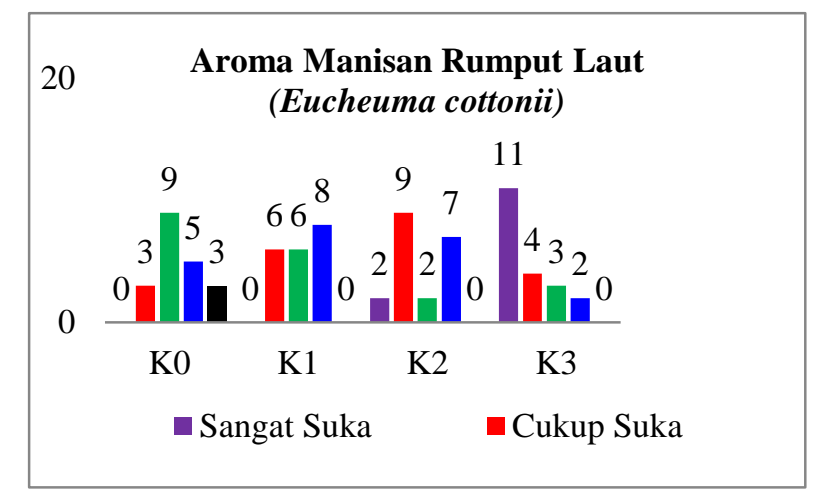

Gambar 4. Histogram tingkat kesukaan panelis terhadap aroma manisan rumput Laut dengan jenis konsentrasi gula yang berbeda dengan penambahan kayu manis.

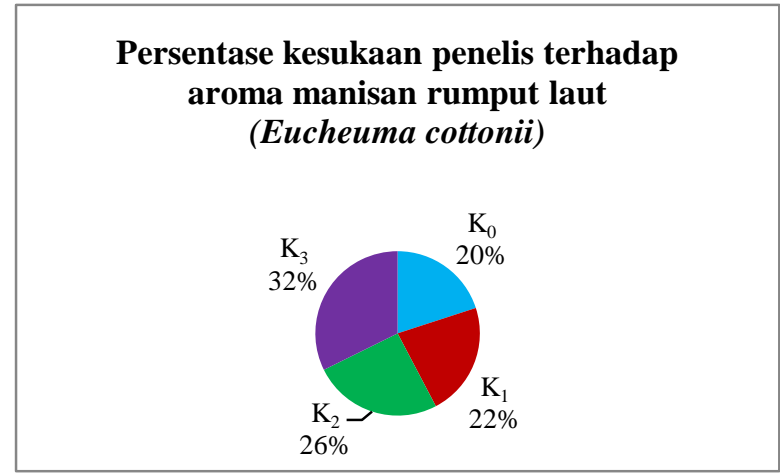

Gambar 5. Persentase penelis terhadap aroma manisan rumput laut dengan jenis gula yang berbeda dengan penambahan kayu manis.

Pada gambar 5 memperlihatkan bahwa panelis lebih menyukai aroma dari perlakuan $\mathrm{K}_{3}$ dengan persentase $32 \%$ dibandingkan dengan perlakukan $\mathrm{K}_{1}$ yaitu $22 \%$, dan $\mathrm{K}_{2}$ yaitu $26 \%$ karna penambahan kayu manis dengan konsentrasi gula yang berbeda dapat memberikan pengaruh yang berbeda pula pada tingkat kesukaan panelis pada aroma manisan rumput laut sehingga pada perlakuan $\mathrm{K}_{0}$ (kontrol) yaitu $20 \%$ yang memiliki aroma bauh amis dari rumput yang masih tercium. Hal ini dikarenakan pada saat pencampuran kayu manis pada tiap perlakuan dengan konsentrasi gula yang berbeda dapat memberikan aroma pada kayu manis yang berbeda pula tiap perlakuan. Hal ini didukung oleh penelitian Rismundar dan Paimin (2001), yaitu dengan pemberian larutan pada kayu manis pada manisan rumput laut memberikan perubahan aroma signifikan, hal ini disebabkan 
karna kayu manis yang mengandung kumarineugenol sehingga aroma yang timbul seperti aroma jamu. Salah satu faktor yang berpengaruh dalam manisan rumput laut dengan penambahan kayu manis adalah pengaruh konsentrasi gula berbeda yang menyebabkan penelis lebih tertarik pada gula yang lebih tinggi karna memiliki aroma yang seimbang antara kayu manis dan gula pada saat proses pengeringan yang tidak terlalu tercium pada saat proses pengeringan.

\section{c. Rasa}

Rasa adalah perasaan yang dihasilkan oleh barang atau sesuatu yang dimasukkan ke dalam mulut yang dirasakan oleh indera rasa yaitu lidah. Secara umum ada empat rasa dasar yaitu manis, pahit, masam, dan asin (Gaffar R dkk 2017).

Untuk lebih jelasnya dapat dilihat tingkat penerimaan panelis terhadap nilai rasa manisan rumput laut (Eucheuma cottonii) dengan jenis konsentrasi gula yang berbeda pada gambar 6 .

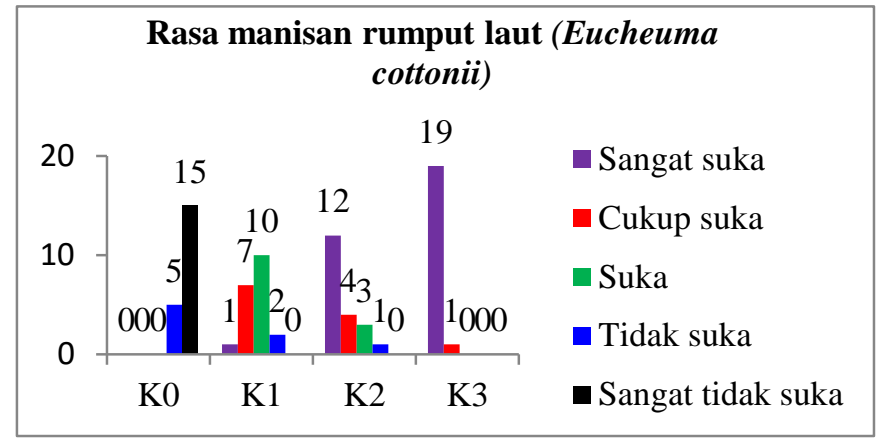

Gambar 6. Histogram tingkat kesukaan panelis terhadap rasa manisan rumput Laut dengan jenis konsentrasi gula yang berbeda dengan Penambahan kayu manis.

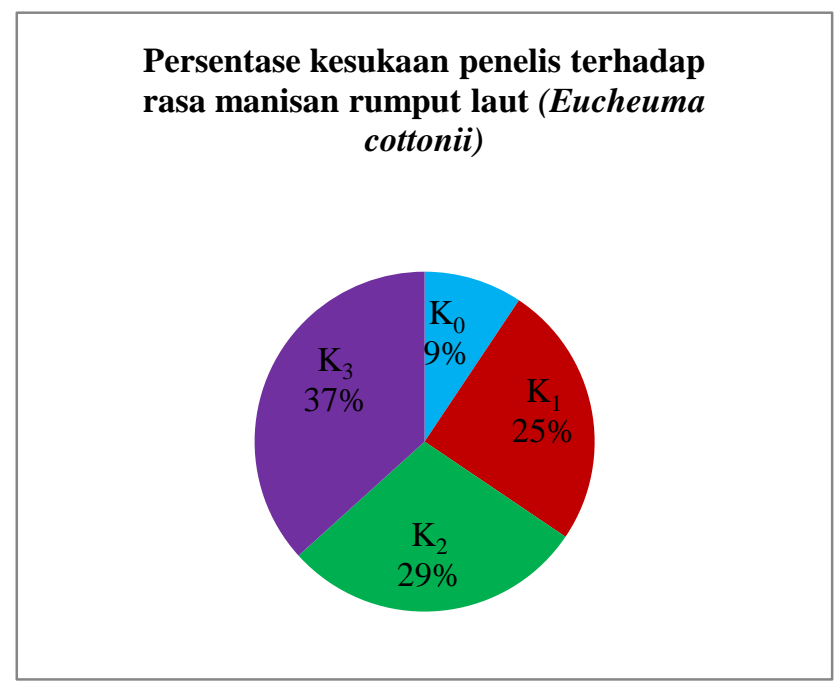

Gambar 7. Persentase penelis terhadap rasa manisan rumput laut dengan jenis gula yang berbeda dengan penambahan kayu manis.

Pada gambar 7 memperlihatkan bahwa dengan penambahan kayu manis pada manisan rumput laut dengan konsentrasi gula yang berbeda memberikan pengaruh nyata terhadap tingkat kesukaan penelis pada rasa manisan rumput laut. Hal ini menunjukan bahwa penambahan kayu manis pada manisan rumput laut dengan konsentrasi gula yang berbeda memberikan perubahan rasa yang signifikan, hal ini disebabkan kayu manis mengandung komponen utama berupa sinnamaldehid yang merupakan komponen minor flavor sehingga bila dicampurkan dalam bahan makanan akan mempengaruhi rasa dari makanan tersebut (Ho dkk.1992). Penilaian penelis terhadap rasa manisan rumput laut dengan penambahan kayu manis dengan konsentrasi gula yang berbeda lebih disukai 
pada perlakuan $\mathrm{K}_{3}$ dengan persentase $37 \%$ karena memiliki rasa yang manis dibandingkan dengan perlakuan $\mathrm{K}_{0} 9 \%, \mathrm{~K}_{1} 25 \%$, dan $\mathrm{K}_{2} 29 \%$.

\section{d. Tekstur}

Tekstur mempunyai peran penting pada daya terima makanan. Penilaian pada tekstur antara lain dengan menilai kehalusan dan kekenyalan terhadap produk yang dihasilkan dan merupakan salah satu parameter yang merupakan kombinasi dari keadaan fisik suatu makanan dan diindra oleh sentuhan penglihatan dan perabaan (kinestesi dan mouthfeel). Keadaan fisik suatu makanan meliputi ukuran, bentuk, jumlah, sifat dasar dan struktur elemennya (Cerpenter dkk. 2000)

Tingkat kesukaan panelis terhadap bentuk atau tekstur manisan rumput laut (Eucheumacottonii) dapat dilihat pada gambar 8 .

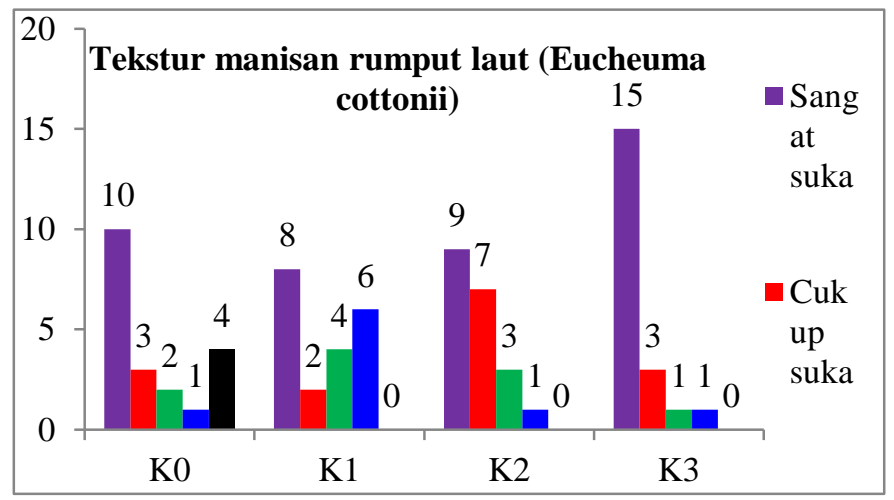

Gambar 8. Histogram tingkat kesukaan panelis terhadap tekstur manisan rumput laut dengan jenis konsentrasi gula yang berbeda dengan penambahan kayu manis.

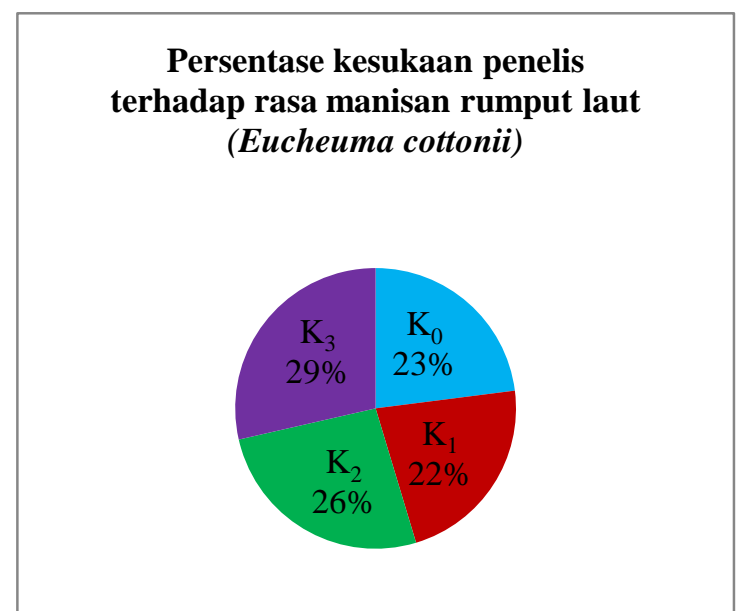

Gambar 9. Persentase penelis terhadap rasa manisan rumput laut dengan jenis gula yang berbeda dengan penambahan kayu manis

Pada gambar 9 memperlihatkan bahwa dengan penambahan kayu manis pada manisan rumput laut dengan konsentrasi gula yang berbeda memberikan pengaruh berbeda pula pada tingkat kesukaan penelis terhdap tekstur manisan rumput laut. Hal ini dukung oleh penelitian Riyadi (2007) yaitu pada manisan kering yang memiliki tekstur agak kenyal karna pengaruh proses pengeringan. Sehinggaa pada perlakuan $\mathrm{K}_{3}$ manisan rumput laut memiliki tekstur yang kenyal karna pengaruh proses pengeringan dengan persentase $29 \%$, dibandingkan perlakuan $\mathrm{K}_{0} 23 \%, \mathrm{~K}_{1} 22 \%$, dan $\mathrm{K}_{2} 26$ $\%$.

\section{Analisis Kadar Air}

Air merupakan komponen penting dalam bahan pangan karena dapat mempengaruhi tekstur, penampakan dan citarasa makanan (Winarno, 1997). Kandungan air dalam bahan pangan juga ikut 
menentukan daya terima, kesegaran dan daya tahan produk. Kadar air mempunyai peranan yang penting dalam menentukan daya awet dari bahan pangan karena dapat mempengaruhi sifat fisik,

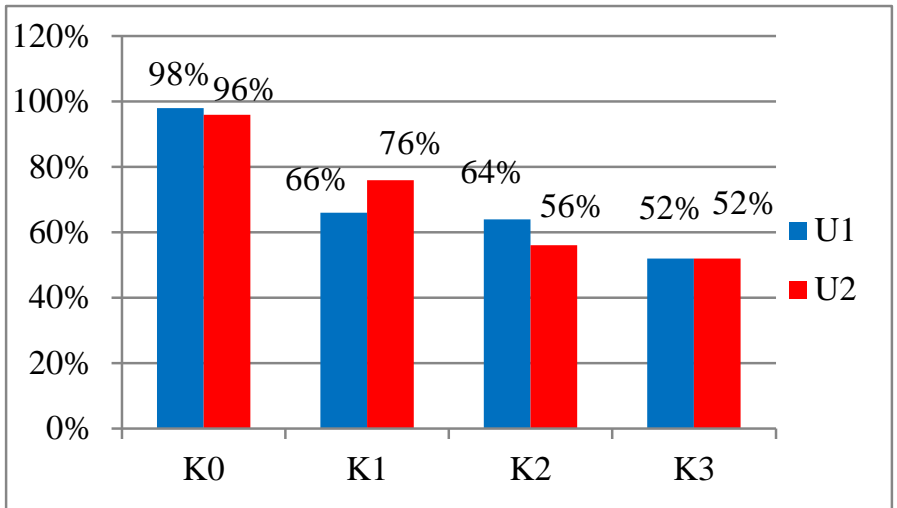

perubahan-perubahan kimia, mikrobiologi dan enzimatis Aryani dkk (2016). Kadar yang tinggi akan mengakibatkan mudahnya kapang, khamir, dan bakteri berkembang biak sehingga berbagai perubahan akan terjadi pada produk yang dihasilkan tersebut (Riyadi 2007).

Gambar 10. Histogram pengujian kadar air pada manisan rumput laut dengan jenis konsentrasi gula yang berbeda dengan penambahan kayu manis.

Pada gambar 10 memperlihatkan bahwa kadar air ma nisan rumput laut (Eucheuma cottonii) dengan konsentrasi gula yang berbeda berkisar antara 96\% - 52\%. Kadar air tertinggi terdapat pada perlakuan $\mathrm{K}_{1}$ dan $\mathrm{K}_{2}$ karena memiliki konsentrasi gula yang rendah. Sedangkan kadar air yang rendah diperoleh dari perlakuan $\mathrm{K}_{3}$ karena memiliki kadar gula yang tinggi sehinggi kadar air yang terdapat dalam manisan rumput laut menjadi rendah. Hal ini disebabkan karena kadar gula yang terdapat dalam manisan juga dapat mengurangi kadar air yang terdapat pada manisan rumput laut dan pada saat proses pengeringan manisan dalam oven.

Menurut Arsa dan Made (2016), kadar air merupakan banyaknya air yang terkandung dalam bahan pangan yang dinyatakan dalam persen. Kadar air dalam bahan pangan ikut menentukan kesegaran dan daya awet bahan pangan tersebut. Hasil analis menunjukan bahwa setiap perlakuan memberikan pengaruh yang sangat nyata terhadap kadar air selai kulit jeruk bali . Semakin tinggi konsentrasi gula yang ditambahkan, maka kadar air selai semakin rendah. Menurut Siregar dkk. (2015), gula memiliki sifat osmosis (menyerap air) sehingga kadar air dalam selai semakin menurun seiring bertambahnya konsentrasi gula. Gula bersifat osmosis sehingga dapat menarik air dari dalam bahan sehingga kadar air bahan menjadi rendah dan tidak tersedia untuk digunakan mikroorganisme. Selain itu menurut Desrosier (2008), kadar air produk pangan dipengaruhi oleh proses pemasakan karena kadar air selai akan mengalami penurunan selama proses pemasakan. Proses yang terjadi yaitu panas yang ditimbulkan oleh pemasakan masuk ke dalam bahan yang kemudian menggantikan kandungan air yang keluar menjadi uap.

Standar maksimum kadar air SNI 2008 adalah $25 \%$ (Putri R.M.S dkk. 2015) sehingga dari perlakuan $\left(\mathrm{K}_{1}-\mathrm{K}_{3}\right)$ yang ada maka perlakuan $\mathrm{K}_{3}$ yang dapat memenuhi standar SNI 2008 karena memiliki kadar air yang rendah karna dapat mempengaruhi daya awet dari bahan pangan dari pengaruh sifat fisik, perubahan kimia dan mikrobiologi sehingga manisan rumput laut dapat bertahan lama selama penyimpanan.

Kemudian (dapat diganti dengan kata yang lain) dilanjutkan dengan pengujian gula total di Laboraturium Pangan Badan Pengawasan Obat dan Makanan (BPOM) Nusa Tenggara Timur (NTT)

\section{Kadar Gula Total}

Gula reduksi adalah gula yang mempunyai kemampuan untuk mereduksi karna mempunyai gula aldehid atau keton bebas. Dalam Astuti dan Rustanti (2014), Contoh gula yang termasuk gula reduksi adalah glukosa, monosa, fruktosa, laktosa dan maltosa. Pengukuran gula totalpenting dilakukan karna gula menentukan karakteristik bahan makanan (warna, rasa, tekstur) terutama pada produk manisan. Gula merupakan komponen penting dalam pembuatan manisan kering. Fungsi larutan gula yang utama adalah sebagai pemanis dan pengawet (Riyadi, 2007). 
Gula mempunyai sifat yang dapat menyebabkan reaksi pencoklatan yaitu karamelisasi (Yunita, 2013). Bila suatu larutan sukrosa diuapkan maka konsentrasinya akan meningkat, demikian juga titik didihnya. Keadaan ini akan terus berlangsung sehingga seluruh air menguap semua. Bila keadaan tersebut telah tercapai dan pemanasan diteruskan, maka cairan yang ada bukan lagi terdiri dari air tetapi cairan sukrosa yang lebur. Titik lebur sukrosa adalah $160^{\circ} \mathrm{C}$ bila gula yang telah mencair tersebut dipanaskan terus sehingga suhunya melampaui titik leburnya, maka mulailah terjadi karamelisasi sukrosa. Hasil reaksi tersebut menghasilkan bahan berwarna cokelat, yang dikehendaki atau menjadi pertanda penurunan mutu (Gaffar dkk. 2017).

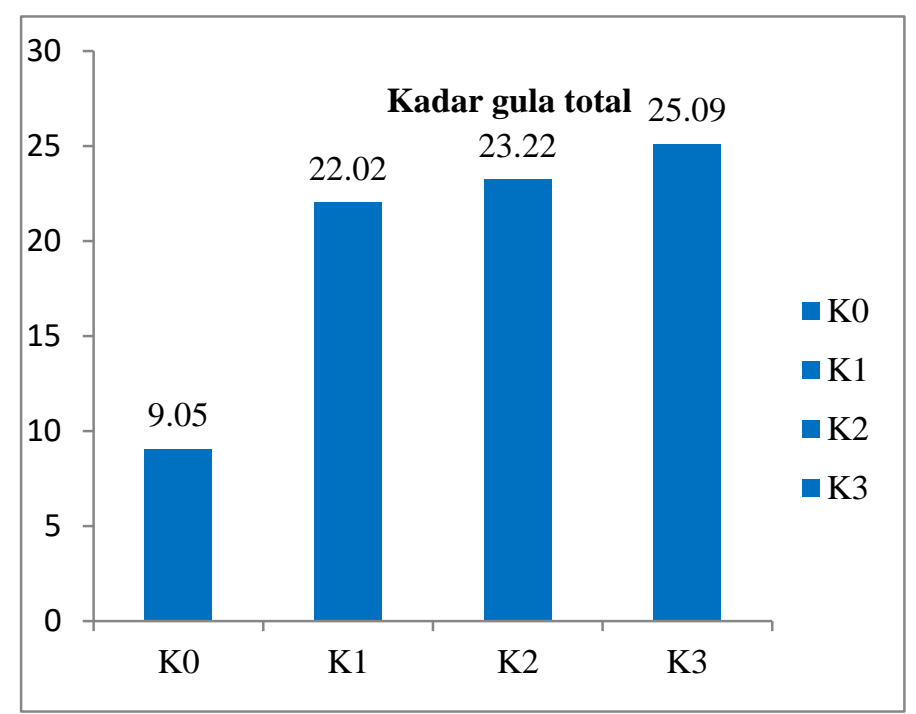

Gambar 11. Histogram pengujian kadar gula total pada manisan rumput laut dengan jenis konsentrasi gula yang berbeda dengan penambahan kayu manis.

Dari gambar 11 diperoleh nilai total gula yaitu 9,05-25,09\%. Pada konsentrasi $\mathrm{K}_{0}$ nilainya sangat rendah karna sebagai kontrol (tanpa penambahan gula dan kayu manis) kemudian diikuti dengan perlakuan $\mathrm{K}_{1}, \mathrm{~K}_{2}$ dan diperoleh nilai gula tertinggi yaitu pada konsentrasi $\mathrm{K}_{3}$ karna memiliki kadar gula yang lebih tinggi yaitu $25,09 \%$ sehingga dapat memenuhi syarat dari SNI tahun 2008 yaitu $25 \%$ . Hal ini menunjukan karna semakin banyak kandungan gula yang ada maka, persentase gula total semakin tinggi sehingga manisan rumput laut lebih manis dan tidak mengalami pencoklatan. Hal ini didukung oleh penelitian Sidauruk dan Mutiara Y (2010), kadar gula total dipengaruhi oleh jumlah gula yang ditambahkan pada sutau produk. Semakin banyak gula yang ditambahkan, semakin tinggi pula kadar gula total suatu produk.

Pemberian gula pada manisan rumput laut dapat berfungsi sebagai bahan pengawet karna sifatnya yang dapat mengurangi kadar air. Semakin tinggi hidrogen gula maka semakin rendah kadar airnya. Gula akan meninggkatkan tekanan osmosis larutan yang dapat mengakibatkan plasmolisis sel mikroba. Penambahan gula dalam konsentrasi tinggi (paling sedikit $40 \%$ padatan terlarut) mengakibatkan sebagian gula yang ada dalam rumput laut menjadi tidak dapat digunakan untuk pertumbuhan mikroba (Riyadi 2007)

\section{PENUTUP}

\section{KESIMPULAN}

Berdasarkan pengujian organoleptik skala hedonik pada manisan rumput laut menunjukan bahwa perlakuan K3 (penambahan gula sebanyak $100 \mathrm{gr}$ dan kayu manis $10 \mathrm{gr}$ ) memiliki tingkat kesukaan yang paling disukai panelis dari aspek aroma, rasa dan tektur. Untuk aspek warna K0 (tanpa penambahan gula dan kayu manis) lebih disukai oleh panelis. Pada pengujian kadar air memperlihatkan bahwa semakin rendah konsentrasi gula yang ditambahkan dalam manisan rumput laut kering maka semakin tinggi kadar air yang terdapat dalam manisan kering rumput laut, sebaliknya semakin tinggi kadar gula yang ditambahkan dalam manisan kering rumput laut maka semakin rendah kadar air yang terdapat dalam manisan kering tersebut sehinga mampu bertahan 
dalam penyimpanan. Pada pengujian gula total dalam manisan rumput laut dipengaruhi pula oleh konsentrasi gula yang ditambahkan sehingga semakin rendah konsentrasi gula maka semakin rendah pula gula total yang ada dalam manisan tersebut demikian juga semakin tinggi konsentrasi gula yang terdapat dalam manisan rumput laut kering maka semakin tinggi pula kadar gula total yang ada dalam manisan rumput laut kering .

\section{SARAN}

Sebagai kelanjutan dari penelitian ini disarankan untuk dilakukan penelitian lanjutan tentang pengaruh penyimpanan terhadap manisan kering rumput laut serta cara dan jenis pengemasan yang cocok selama penyimpanan. Perlu juga untuk memberi perlakuan zat pewarna alami yang dapat memberikan warna yang lebih disukai oleh panelis.

\section{DAFTAR PUSTAKA}

Anggadiredja, J.T., Zatnika, A., Purwoto, H., \& Istini, S. 2006. Rumput Laut. Jakarta. Penebar Swadaya. Hal 133

Arsa, M. 2016. Proses Pencoklatan (Browning Process) Pada Bahan Pangan.Universitas Udayana Denpasar.

Buckle, K.A., Edwards, R.A., Fleet, G.H., \& Wooton, M. 1987. Ilmu Pangan. Hari Purmono Dan Adiono Penerjemahan. Jakarta : UI Press

Darti, N dan Amar, R.N.A. 2011. Modul Pembelajaran Bidang Pangan: Pengolahan Hasil Pertanian, Perikanan Dan Kelautan. Hal 81

Desrosier, N.W. 2008. Teknologi Pengawetan Bahan Pangan. Penerjemah M. Muljohardjo. UI Pres. Jakarta.

Dharma, S.A.P.W.K., Dewi, I.M.S., \& Darmasetiyawan. 2016. Pelatihan Pengolahan Produk Rumput Laut Untuk pengembangan mendukung Nusa Lombongan sebagai destinasiwisata. Jurnal Udayana Mengabdi., Vol.15 No.2

Farel, K.T. 1985. Spice, Condiments And Seasoning. The Avi Book Publihsed by Nostran Reinhold Co, Newyork

Fikral, I., \& Novelina, KS. 2016. Pembuatan Nori Dengan Pemanfaatan Kolang Kaling Sebagai Bahan Subtitusi Rumput Laut Jenis Eucheuma Cottonii. Fakultas Teknologi Pertanian. Universitas Andalas.

Firdarini, R.I. 2016. Teknik Produksi Dodol Rumput Laut (Eucheuma cottoni). Laporan praktek pengalaman langan, Proggram Studi S-1 Budidaya Perairan. Fakultas Prikanan dan Kelautan. Universita Airlangga Surabaya.

Gaffar, R, Lahming, M.R. 2017. Pengaruh Konsentrasi Gula Terhadap Mutu Selai Kulit Jeruk Bali (Citrus Maxima). Jurnal Pendidikan Teknologi Pertanian, Vol. 3 (2017) : S117-S125

Ghufran, M.H.K.K. 2010. Budidaya Biota Akuatikuntuk Pangan, Kosmetik, dan Obat-obatan. Lily Publisher. Yogyakarta.

Hamid, A. 2009. Pengaruh Berat Bibit Awal Dengan Metode Apung (Floating Method). Terhadap Presentase Pertumbuhan Harian Rumput Laut Eucheuma Cottonii, Jurusan Biologi Sains dan Teknologi, Universitas Islam Negeri (UIN)

Hamzah F. \& Sribudiani. E. 2010. Mutu Manisan Kering Buah Naga Merah : Laboraturium Fakultas Teknologi Pengolahan Hasil Pertanian Riau. Jurnal Volume 9 No 1:15-20

Idman, D. 2010. Optimasi formula permen jelly rumput laut (Kappaphycusalvarezii) dan Pendugaan Umur Simpan Daya Dengan Model Pendekatan Kadar Air Kritis Yang Dimodifikasi. Fakultas Perikanan dan Kelautan Institut Pertanian Bogor

Istini, S., Zantika, A., Suhaimi, \& Anggadireja, J.T. 1986. Manfaat Dan Pengolahan Rumput Laut. Jakarta BPPT

Joseph, G., Lana Laluan, S., Sumual, M.F. 2017 Pengaruh Sukrosa Terhadap Karakteristik Fisikokimia dan Sensoris Manisan Kering Paprika Merah (Capsicumannum vargrossum). Vol.1, Nomor 7 Tahun 2017

Kadir, S. 2000. Studi Kandungan Gizi Juice Rumput Laut. Tesis IImu Kesehatan Masyarakat Unair Surabaya 
Khan A., Sufdar, M., Khan M.M.A., Khatak, K.N., \& Anderson, R.A. 2003. Cinnamon Improves Glukose And Lipids Of People Whit Tipe 2. Diabetes Care 26:3215-3218

King, R.A. 2000. The Role Of Polyphenol In Human Health. Didalam J.D Broker (Ad) Tannins In Livestock And Human Nutrition. ACIAR Proceedings No 92

Kusumaningrum, R., Supriadi, A.. \& Hanggita, R.J. 2013. "Karakteristik Dan Mutu Teh Bunga Lotus (Nelumbo Nucifera)",Fakultas Pertanian Universitas Sriwijaya Indralaya Ogan Ilir. Jurnal Fishtech Vol II.

Maria, A.T. 2013 Pengaruh Penambahan Konsentrasi Gula Yang Berbeda Terhadap Mutu Sirup Nenas (Ananascomosusl. Merr) Lewat Masak Yang Dihasilkan. JurusanTeknologi Pertanian Politeknik Pertanian Negeri Samarinda Samarinda

Mulyadi, A., Maligan, J.W., \& Hermansyah, R. 2013. "Karakteristik Organoleptik Serbuk Perisa Dari Cangkang Rajungan (Portunuspelagicus): Kajian Konsentrasi Dekstrin Dan Suhu Pengering", Jurnal Teknologi Pertanian Vol.14 No. 3 Hal. 183 - 192.

Pongarrang, D.R.A \& Iba, W. 2013. Pengaruh Jarak Tanam dan Bobot Bibit Terhadap Pertumbuhan Rumput Laut (Kappaphycusalvarezii) Menggunakan Metode Vertikultur. Jurnal Mina Laut Indonesia. 3(12):94- 112.

Rahmah, G.L.M.R. 2017 Pengaruh Konsentrasi Gula Terhadap Mutu Selai Kulit Jeruk Bali (Citrus Maxima) Jurnal Pendidikan Teknologi Pertanian, Vol. 3 (2017) : S117-S125

Putri, R.M.S., Retty, N., \& Sari A.G. 2015. Pengaruh Jenis Gula Yang Berbeda Terhadap Mutu Permen Jelly Rumput Laut (Eucheuma Cottonii). Jurnal Teknologi Pertanian Andalas Vol.19 No.1 ISSN 1410-1992

Risamasu, J.L.F. 2014. Kajian Kondisi Sumberdaya Kelautan Dan Perikanan Di Provinsi NTT Kepala Pusat Penelitian Perikanan dan Kelautan Lembaga Penelitian Undana, dan Dosen Fakultas Kelautan dan Perikanan Undana

Rismundar \& Paimin, F.B. 2001. Kayu Manis : Budidaya dan Pengolahan. Penebar Swadaya. Jakarta

Rizal, A., Nami, L., \& Reno, F. 2013. Kajian Mutu Pengolahan Rumput Laut Eucheuma Sp.

Riyadi Dody. 2007. Pemanfaatan Rumput Laut (Eucheuma cottonii) Dalam Pembuatan Manisan Dengan Penambahan Kayu Manis. Fakultas Perikanan dan Kelautan Institut Pertanian Bogor

Rusli, S. \& Abdullah A. (1988). Prospek Pengembangan Kayu Manis di Indonesia. Jurnal LitbangPertanian, VIII (3), hal. 75-79.

Sidauruk, M.Y. 2010. Studi Pembuatan Selai Campuran Dami Nangka (Artocarpus heterophyllus) dengan Belimbing Wuluh (Averrhoa bilimbí L.).

Siregar, E.A., Herla, R., \& Limbong, L.N. 2015. Pengaruh Lama Blansing dan Jumlah Gula Terhadap Mutu Manisan Basah Sawi Pahit. Jurnal Rekayasa Pangan dan Pertanian. Vol.3, No 02. Program Studi IImu dan Teknologi Pangan Fakultas Pertanian Universitas Sumatera Utara Medan.

Yusmiati, S.N.C.. 2003. Kandungan Gizi (Kalori, Protein, Yodium, Serat) Dan Mutu Organoleptik Cookies Rumput Laut Pada Berbagai Konsentrasi Penambahan Rumput Laut Eucheuma cottonii. Program pascasarjana, Universitas Airlangga. Surabaya SNI 01-2892-1992. Balai Pengawasan Obat dan Makanan (BPOM) Kupang Nusa Tenggara Timur

Soleh, A., Ghanaim, A.F., \& Rachmawati, N. 2015. Extraction, Tocity Assay And Identification Of Active Compounds Of Red Alga (Eucheumacottonii) From Sumened Madura. Jurusan Kimia Fakultas Sains dan Teknologi, Universitas Islam Negeri Maulana.Vol.4 No.2 tahun 2015 hal. 101-106

Suhardjo. 1992 Pemanfaatan Pangan Sumber Yodium Dalam Upaya Penanggulangan GAKY. Pau Pangandan Gizi. Institute Pertanian Pertanian Bogor

Surati, N.I., \& Kilbaren, S.W. 2016 Potensi Rumput Laut Sebagai Bahan Dasar Pembuatan Makanan. Program studi Biologi IAIN Ambon. Biologi Sel (Vol.5 No.2 Edisi Juli-Desember 2016 ISSN 2252-858X / E ISSN 2541-1225) Hal.93

Uswaton, K. 2013.,Analisis Kesesuaian Perairan Untuk Lokasi Budidaya Rumput Laut Eucheuma Cottonii Di Perairan Kecamatan Sajoanging Kabupaten Wajo. Fakultas IImu Kelautan Dan Perikanan Universitas Hasanuddin Makassar 
Suri, W. A. 2014, Pertumbuhan Rumput Laut Eucheuma Cottonii Pada Kedalaman Air Laut Yang Berada Di Desa Eti Kecamatan Seram Barat, Kabupaten Seram Bagian Barat. Program studi pendidikan Biologi. Biopendix, 1 (1) 2014

Winarno, F.G. 1984. Kimia Pangan dan Gizi. PT Gramedia Jakarta

Winarno, F.G. 1990. Teknologi Pengolahan Rumput Laut. Pustaka Sinar Harapan. Jakarta.

Winarno, F.G. 1997 Naskah Akademis Keamanan Pangan. IPB. Bogor

Yenrina, R. 2015. Metode Analisis Bahan Pangan dan Komponen Bioaktif. Padang: Andalas University Press.

Yunita, S. 2013. Pengaruh Jumlah Pektin Dan Gula Terhadap Sifat Organoleptik Jam Buah Naga Merah (Hylocereus Polyrhizus). Universitas Negeri Surabaya. 